\title{
Advancing the contextual factors impeding the development of aquapreneurship in Cameroon
}

\author{
Bernard Lama Ngota
}

\section{A B S T R A C T}

Objective: The objective of this article is to examine the contextual factors impeding the growth and development of aquapreneurship in Cameroon.

Research Design \& Methods: The empirical study was conducted during November and December on a sample of 195 aquapreneurs in the Littoral, West, and Central regions of Cameroon. The study employed self-administered structured questionnaires and individual invitations were sent out to aquapreneurs in these regions. To compile the results, 150 completely filled-out questionnaires were used.

Findings: Findings revealed that fish farmers faced several challenges including the high cost of constructing, filling, and managing ponds, the high rate of fish predators, fish death due to diseases, the high cost of feed, and the lack of financing, industries to manufacture quality fish feed, and space to expand fishponds.

Implications \& Recommendations: The study recommends all-encompassing measures by the government regarding awareness through education, the production of fingerlings at low cost to farmers, encouraging new entrants in fish feed manufacturing industries, and credit policies to accommodate aquapreneurs and improve incorporation into the globalised economy.

Contribution \& Value Added: This study is significant because it highlights the plight of aquapreneurs in a developing country such as Cameroon and brings to the fore the challenges this sector encounters to develop the aquaculture industry.

\begin{tabular}{|c|c|}
\hline Article type: & research article \\
\hline Keywords: & $\begin{array}{l}\text { aquapreneurship; Cameroon; entrepreneurial challenges; fingerlings; } \\
\text { fish farming; ponds }\end{array}$ \\
\hline JEL codes: & J15, L26, M10 \\
\hline Received: $11 \mathrm{~N}$ & Accepted: 17 August 2020 \\
\hline
\end{tabular}

\section{Suggested citation:}

Ngota, B.L. (2020). Advancing the contextual factors impeding the development of aquapreneurship in Cameroon. Entrepreneurial Business and Economics Review, 8(3), 65-82. https://doi.org/10.15678/EBER.2020.080304 


\section{INTRODUCTION}

Fish consumption has recently increased worldwide with high demands in the developing countries that get most of their catches from the wild (FAO, 2004, 2015). Fish is a preferred protein source for most Cameroonians because it is cheap compared with other meats such as bushmeat, pork, chicken, and beef. An important source of protein in the human diet on a worldwide gauge, it is predicted that fish form the most significant source of protein and it is suggested that more than $30 \%$ of all fish consumable for humans comes from aquaculture (Frimpong \& Adwani, 2015; Håstein, Hjeltnes, Lillehaug, Skåre, Berntssen, \& Lundebye, 2006). This has posed an enormous increase of demand for fish and fish product for food in Cameroon. Over the past decades, aquaculture has advanced to turn into the firmest rising food producing segment globally (Frimpong \& Adwani, 2015). The FAO (2015) asserts that an outsized amount of fish is produced by small-scale fish farmers. Consistently, some authors (Håstein et al., 2006; Frimpong \& Adwani, 2015) attest that freshwater produces more than $80 \%$ of aquacultural products. Aquaculture started in Asia and - since then - it has experienced enormous progress to become the highly specialised field it is today.

Some authors (Ifejika, Oladosu, Asadu, Ayanwuyi, Sule, \& Tanko, 2015; Ifejika, 2015) indicate that practising aquaculture amplified fish farming practices with an observable economic impact in areas such as nutrition and food security, poverty reduction and employment, economic growth, business venture, and the improved standard of living for aquapreneurs. Similar studies on aquapreneurship by Ifejika (2015) establish that fish and fish products improved significantly from $5.01 \%$ in 2001 to $23.61 \%$ in 2010 . Moreover, Miller and Atanda (2010) suggest a $20 \%$ upsurge in the yearly progression of aquacultural products, with a huge progress in small-to-medium businesses and a number of large-scale highly sustained fish farms. In the context of this study, aquapreneurs means individuals who rear fish for commercial purposes (Ifejika et al., 2015). In other words, to sustain aquaculture to become lucrative at a tolerable standard for aquapreneurs and other investors, distinctive consideration needs to be given not just to the supply and demand of aquacultural products but also to the economic and financial management of the sector.

Regardless, aquaculture is noted to be a momentous provider to the social and economic growth of developing nations such as Cameroon, the predicament of aquapreneurs-owned trades that govern this segment has been fundamentally deserted over the past decades in policy and provision ingenuities (Brummett, Gockowsky, Pouomogne, \& Muir, 2011). Mwangi (2008) and Osure (2011) states that the uncoordinated promotion of fish farming by many institutions, governments, research institutions, universities, NGOs, and regional authorities is the challenge facing fish farming development in Africa. Pouomogne and Pemsl (2008) state that prospects of aquaculture - if some of the challenges were restrained - in Cameroon seem bright especially for fish farming, no matter the scale of production. Challenges include the lack of capital, infrastructure, technical support, poor quality fingerlings and feed, few talents, poor marketing, and management (Pouomogne \& Pemsl, 2008). Eventually, these challenges have affected productivity and profitability levels in this sector. The direct consequence is an increased level of neglected fishponds. Furthermore, most aquapreneurs invest in fish farming primarily for profit, which elucidates the increased number of neglected fishponds due to adverse results (Brummett et al., 2011; Pouomogne \& Pemsl, 2008). Disregarding the incidence of these 
investigations, consideration is thus far needed to address the challenges that disrupt the growth of aquapreneurship in Cameroon. Moreover, the challenges impeding the initiation, growth, and development of this sector were not investigated in the framework of aquapreneurship development in Cameroon. Therefore, this study deals with impeding factors that face aquapreneurship in Cameroon, determined the problems faced by aquapreneurs and identified the factors that affect investment in fish farming in Cameroon. This study is significant because the assessment of impeding factors facing aquapreneurial development will further serve as a framework for formulating new and better policies for aquapreneurial development in Cameroon.

The main objective of this study was to examine the contextual factors impeding the growth and development of aquapreneurship in Cameroon. To address the aforementioned theme, the study presents three sub-objectives, namely:

1. To determine the source through which aquapreneurs get their fingerlings and the challenges they encounter.

2. To determine whether the cost involved in the construction and managing of fishponds harm large scale fish production in selected regions in Cameroon.

3. To determine the challenges that appear to hamper fish farming/aquapreneurship in the selected regions in Cameroon.

This paper is presented in the subsequent arrangement: in the next section, the literature on entrepreneurship perspective in Africa, the concept of aquaculture, the development of aquaculture, contributions and professed constraints in Cameroon followed by sustainable development of aquapreneurship. Thirdly, the research material and methods for the study. Fourthly, the results and discussion are presented. Finally, the concluding remarks are presented.

\section{LITERATURE REVIEW}

\section{Entrepreneurship Perspective in Africa}

Empirical studies on entrepreneurship in the African continent remain nascent and receive little attention from scholars (Dvouletý \& Orel, 2019). However, and despite limited research, there have been numerous efforts over the past two decades to promote the knowledge of entrepreneurial activities in the African continent (Frese \& de Kruif, 2000; Kiggundu, 2002; Sriram, \& Mersha, 2010; Kshetri, 2011; Munemo, 2012; Röschenthaler \& Schulz, 2015; Kuada, 2015; George, Kotha, Parikh, Alnuaimi, \& Bahaj, 2016; Lashitew \& van Tulder, 2017; Atiase, Mahmood, Wang, \& Botchie, 2018; Ratten \& Jones, 2018; Dvouletý \& Orel, 2019). Dvouletý and Orel (2019) and Rey (2018) note the continuous entrepreneurial transformation in the African continent and distinguish that with the adoption of a pan-Africanism mindset, the majority of African countries are undergoing a digital rebirth, which increases their connectedness and opens markets. Ratten and Jones (2018) argue that entrepreneurial activity is lower in the African continent compared to other regions of the world. These authors note that the aforementioned is due to the past emphasis of governments to control businesses, which discourages private investments in new enterprises such as the aquacultural sector. However, Africa is finally witnessing a transformation as the continent exhibits one of the highest entrepreneurial intents globally. 
Dvouletý and Orel (2019) state that entrepreneurship shows a rebirth across the African continent, with overflowing entrepreneurial activities as the potential tool for solving Africa's socio-economic challenges by creating jobs and impacting GDP growth, if countries overcome structural challenges. Some scholars (Chigunta, 2017; Dvouletý, Gordievskaya, \& Procházka, 2018) theorise that there is a shift in African countries from the traditional sources of income to experiencing an increasing entrepreneurial activity, more often visible not only as a sustainable job-generating tool but a lead route to economic growth and development.

Although many countries in the African continent have not yet conducted the Global Entrepreneurship Monitor (GEM) for scholars to study their entrepreneurial activities, by relying on existing GEM surveys and other data sources allowed for establishing that entrepreneurial activities in 12 African nations demonstrate the importance of several determinants, which influence the early-stage level of entrepreneurial activity. Nonetheless, the available literature on entrepreneurship focuses on entrepreneurial activities in developed nations (such as the USA, Europe, Australia, and Asia) with huge neglect of entrepreneurship in the aquacultural sector, while the study of the African continent remains minuscule to date.

Despite the large entrepreneurial focus globally towards innovation, technology, manufacturing, and the trade of goods and services as entrepreneurship instruments for economic growth and development, little research focused on the impact of agriculture and aquacultural production as economic enhancers. Therefore, this article brings to the fore the dilemmas of aquapreneurs as the vital element of economic growth and development in a developing country such as Cameroon. Somerville, Cohen, Pantanella, Stankus, and Lovatelli (2014) suggest that the production of domestic food, access to markets, and acquisition of skills are invaluable instruments for securing the empowerment and emancipation of developing countries' population, which can be achieved through aquapreneurship. Moreover, the same authors (Somerville et al., 2014) argue that aquapreneurship can offer the basis for the fair and sustainable socio-economic growth of many developing nations of the world, especially in Africa.

\section{The Concept of Aquaculture}

Aquaculture refers to the cultivation of water species, e.g. crustaceans, molluscs, fish and water plants under controlled conditions. In other words, aquaculture may simply mean 'Underwater Agriculture' (Khan, Khan, \& Miyan, 2011). Over the decades, there occurred a drop in profitable yield of fresh fish wild stocks and of other fish products as a response to the enormous rise in the growth rate of aquaculture (Khan et al., 2011). According to Khan et al. (2011), each aquacultural system has a specific set of circumstances, along with a variation of the total biomass produced from one system to another. Therefore, the selection of a specific aquacultural system centres on environmental region, water type, obtainable resources, talented people, targeted water organisms, the accessibility of seed of the targeted water organisms at the needed period, distinct from a set of dissimilar socioeconomic dynamics (Khan et al., 2011). Imperatively, fish and fish products have the highest portion in the number of organisms and production in capacity and worth among all water species used in aquaculture (Khan et al., 2011). Specific fish species or combinations of different compatible fish types could be designated for cultivation in order to yield an increased level of biomass. Khan et al. (2011) suggest that fish may be kept in old-style public fishponds, deprived of the added synthetic diet without the proper maintenance of 
fishponds. However, to get a better return, modern aquaculture practices rely on intensification, wherein very high stocking density of fish are maintained on artificial feed, while water quality and environmental parameters are monitored to remain in the optimal range required for the high growth rate of the fish.

\section{The Development of Aquaculture, Contributions, and Professed Constraints in Cameroon}

Aquaculture in Cameroon began around the 1940s; nevertheless, it is yet to be developed, as it still generates modest production in comparison to other systems of skilful farming (Ndah, Knierim, \& Ndambi, 2011). Some authors (Bigwa, 2013; Sadeu, Mikolasek, Barlet, \& Chia, 2008) allude that aquaculture is conducted in rural areas with fresh aquatic fishponds of about $350 \mathrm{~m}^{2}$ and establish acceptable methods and the diversity of produced aquatic organisms (FAO, 2013, 2015; Pouomogne \& Pemsl, 2008). These fish are nourished with less expensive, natural feed such as plants, weeds, and organic waste from the households. Although in its intensive nature, this aquaculture method can grow profitably, leading to the increased fertilisation of ponds, along with the use of supplementary feed and kitchen manure (Bigwa, 2013). Although aquaculture is practised both in small-scale and large-scale commercial activities, the most predominant aquacultural producers are small-scale farmers (Pouomogne \& Pemsl, 2008). The yearly production of fish and fish products remains trivial, at about 870 tonnes a year; although, there appeared indications of state participation through venture capital to assist the growth and development of this sector. Bigwa (2013) established that fish culture is still at its primary state making fish production in Cameroon to remain low.

The demand for fish as food is steadily growing, and aquaculture established itself as an important source for the supply of excellent quality proteins and healthy oils. According to FAO (2015), aquaculture production is already reaching almost $50 \%$ of the total fish production for human consumption, including marine and freshwater species. Scholars acknowledge that the prospects of fish farming rest with aquaculture (Béné \& Heck, 2005; IUCN, 2007). Godfray, Beddington, Crute, Haddad, Lawrence, Muir, Pretty, Robinson, Thomas, and Toulmin (2010) indicate that aquaculture has a significant positive contribution to food security through extensive and semi-intensive systems of production around the world (FAO, 2015; Lehane, 2013). There are fundamental social and economic differences between extensive/semi-intensive and intensive systems of production, relevant to food security (FAO, 2015). On-farm by-products contain nutritional contributions for semi-intensive production, as they appear to be more affordable than feed used in an intensive system. Due to the low production cost involved in the semi-intensive system, poorer aquapreneurs can afford low-cost inputs thereby making fish to be supplied at considerable and cheaper prices to consumers. Edwards (1997) argues that producing fish intensively at a relatively high cost will only entail profitable marketing at high price due to the costs involved in the production of fish; hence, this will put consumers at a price edge beyond their purchasing power.

Regardless of having a fish-eating convention and considering that aquaculture industry faces instable manageability during its 'quick' improvement in Cameroon, a portion of socio-economic perspectives that impede the development of aquaculture advancement mainly stem from expanding population density with constrained farmland: small land sizes, shortage and poor fishponds inputs, the type of feed that sometimes must be sourced abroad, and the shortage of fingerlings (Oyase \& Jemerigbe, 2016). Since those 
who practise aquaculture mostly live in rural areas, which consist of the poor majority of the population, the lack of income confines their ability to buy quality sources of feed and fingerlings, which are excessively costly. The quality of freshwater aquaculture has been found to influence fish value and acceptance in some cultures and countries (Badr, Salwa, \& Ahmed, 2015). In consequence, freshwater aquaculture is dependably considered to harm freshwater fish. There are likewise issues with insufficient framework advancement like unreliable power that would support the grasping of more detailed outlines (Pouomogne, \& Pemsl, 2008; Sanusi, \& Danasabe, 2015). Researchers (Badr et al., 2015) attest that, in provincial zones, structures of generation, preparation, circulation, and promotion are lacking. Thus, governmental and private area associations interest in the subsector is a requirement to aquaculture development. Moreover, there is no detailed managerial approach to direct aquaculture management. Since fishponds are situated inside rural farmlands, the application of pesticides on farms harm the ponds, particularly during the wet season. Finally, there are predators that feed on fish, which hinders production.

\section{Sustainable Development of Aquapreneurship}

Aquaculture is currently the world's fastest-growing food industry, which accounts for approximately $50 \%$ of total global seafood supply (FAO, 2017). Therefore, sustainable aquaculture growth and development is crucial to easing pressure on wild fish stocks, globally under stress due to overfishing (Brandi, 2017). Goddek, Delaide, Mankasingh, Ragnarsdottir, Jijakli, and Thorarinsdottir (2015) state that the aquaculture sector is challenged with the responsibility of feeding a quickly growing world population, and as global seafood consumption rises, sustainable aquacultural production must increase to keep up with the global demand (Conijn, Bindraban, Schröder, \& Jongschaap, 2018). However, concerns have emerged around the environmental consequences of such growth and development. Scholars (Brandi, 2017; Goddek \& Keesman, 2018) note that with the emergence of innovation and technology, the focus shifted towards the longevity and sustainability of aquaculture. The implementation of certain measures can lead to the sustainable development of aquaculture.

Moving aquaculture into land-based recirculating systems is one of the best ways to reduce or even fully eliminate the environmental impact associated with fish farming. Goddek and Keesman (2018) indicate that the Recirculating Aquaculture System (RAS) gathers technologies that create appropriate conditions for aquaculture by using indoors tanks, pumps, aerators, and filters; with new developments, these can be designed to attain $100 \%$ water recycling within the system. However, the possibilities with the implementation of land-based RAS are endless, as they do not only act as a mitigation strategy for traditional aquaculture's environmental effects but also permit for aquaculture to happen anywhere, including urban and desert regions. Kloas, Groß, Baganz, Graupner, Monsees, Schmidt, Staaks, Suhl, Tschirner, Wittstock, Wuertz, Zikova, and Rennert (2015) concur that offshore systems are marine net pens placed out in the open ocean far from the coastline, which result in a more environmentally-conscious option when land space is an issue and using the ocean is the only alternative. However, the open ocean offers deeper water and more powerful currents than in coastal areas; in turn, this means that offshore aquaculture systems allow for more efficient dilution of waste produced from the farm system. Not only that, offshore waters have fewer nutrients and less biodiversity than fragile coastal waters, enabling the faster dispersion of fish waste into the marine food web, with a lesser environmental impact (Kloas et al., 2015). 
Aquaculture can be sustained through the implementation of multi-trophic aquaculture, which is a cost-effective way to reduce nutrients accumulation by using filter feeders to replace artificially used filters (Junge, König, Villarroel, Komives, \& Jijakli, 2017). The system is advantageous in reducing waste accumulation and assisting the improvement of water quality, all providing additional economic value to the farm. Moreover, the use of renewable energy sources with its marginal cost is one of the best ways to embark on commercial fish farming. Mohtasham (2015) indicates that firms integrated renewable energy systems and aquaculture in several ways, like using wind turbines with installations for shellfish and macroalgae aquaculture, using solar-powered heating and cooling systems, and using wind-powered water pumps. Investing in renewable energy sources to power aquaculture will help to reduce operating costs and boost competitiveness and profitability, and that is before mentioning the reduced environmental footprint. Lastly, scholars (Brandi, 2017; Conijn et al., 2018; Goddek \& Keesman, 2018) believe that making environmentally responsible personal food choices is vital to guaranteeing the future of sustainable aquaculture and fisheries. As a consumer of seafood, being informed on the source of what is on your plate, and buying accordingly, can make a lot of difference to how food is grown and manufactured. Eating from sustainable sources means you are consuming fish raised and caught sustainably, and which does not cause overfishing or damage to the ecosystem. Although the implementation of these factors can go a long way to sustain aquaculture and aquapreneurship, but if underestimated, it might still face some challenges in its complete implementation stage to fruition, such as financial. Thus, this forms the basis of the current investigation.

\section{MATERIAL AND METHODS}

The research gathered the required data during November and December 2017 on a sample of 150 aquapreneurs (owners-managers) who own and operate fish farms in the Littoral, West, and Central regions of Cameroon. The three regions were selected for their high involvement in aquaculture. The sample was drawn from a population of aquapreneurs (owners-managers). The sample population was invited to take part in survey meetings held at selected farms in the regions. Next, the study employed snowball sampling technique to select aquapreneurs. Those who responded to the invitation through referral were requested to participate in the survey. A total of 195 aquapreneurs were referred, of which 150 aquapreneurs were available and able to fill the self-administered structured questionnaires utilised to compile the results, which made it possible to arrive at a high response rate. The actual sampling frame consisted of 65 aquapreneurs in the Littoral region, 40 aquapreneurs in the Central region, and 45 in the West region, which makes the total of 150 aquapreneurs who own fish farms in the three regions. The significant constraint of this investigation was the sample measure, since the definite population estimate was not justified. Specifically, the unavailability of reliable statistics on the existing aquapreneurs in Cameroon, in which case, could not allow establishing the precise population thus was a major hindrance

Furthermore, the use of samples selected using the snowball sampling technique was due to an unlisted database of aquapreneurs in Cameroon. Moreover, due to resource constraints that could restrict each subject in the population to have an equal chance of being selected could lower the legitimacy and dependability of the investigation. Be that 
as it may, this was the most appropriate strategy in the situation because it improved the nature of the gathered information. The complete data of 150 aquapreneurs was analysed descriptively, while inferential statistic, i.e. chi-square, was employed to decide if the observed differences were significant. To test whether there were any significant statistical associations between socio-economic characteristics and participation in fish farming, the study observed gender, age, educational level and marital status.

Ethics-wise, participants were assured of anonymity and the information that could lead to their or their organisations' identification was not revealed. Instead, acronyms were used to ensure confidentiality and protect them from harm. The researcher employed all efforts to obtain participants' consent without coercion. Furthermore, the investigator informed the participants that they could withdraw from the investigation any time and for any reason. Participants were informed of the future use of the data and why their participation was important.

\section{RESULTS AND DISCUSSION}

\section{Background Profile of Participants}

Background attributes of participants were necessary in light of the challenges that aquapreneurs faces. Table 1 demonstrates a cross-tabulation of respondents' background profile with regards to age, gender, and marital status.

Table 1. Cross-tabulation of participants gender, age, and marital status

\begin{tabular}{|c|c|c|c|c|c|c|c|c|c|c|c|}
\hline \multirow{2}{*}{\multicolumn{3}{|c|}{$\begin{array}{c}\text { Marital } \\
\text { status }\end{array}$}} & \multicolumn{5}{|c|}{ Age } & \multirow{2}{*}{ Total } & \multicolumn{3}{|c|}{ Summary of Chi-square tests } \\
\hline & & & \multirow{3}{*}{$\begin{array}{c}19-23 \\
0 \\
(0.0)\end{array}$} & \multirow{3}{*}{$\begin{array}{c}29-33 \\
0 \\
(0.0)\end{array}$} & \multirow{3}{*}{\begin{tabular}{|c|}
$34-38$ \\
26 \\
$(19.5)$
\end{tabular}} & \multirow{3}{*}{\begin{tabular}{|c}
$39-43$ \\
30 \\
$(22.6)$
\end{tabular}} & \multirow{3}{*}{$\begin{array}{c}44 \text { above } \\
52 \\
(39.1)\end{array}$} & & \multirow[t]{2}{*}{ Computed $X^{2}$} & $d f$ & $p$-value \\
\hline \multirow{3}{*}{ 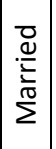 } & & Male & & & & & & \multirow[t]{2}{*}{108} & & & \\
\hline & ర్ & $\%$ & & & & & & & & 3 & $0.000^{*}$ \\
\hline & 心 & $\begin{array}{l}\mathrm{FIVI} \\
\%\end{array}$ & 0 & $\begin{array}{c}3 \\
(23)\end{array}$ & $\begin{array}{c}4 \\
(2)\end{array}$ & 12 & 6 & 25 & 18.890 & 3 & $0.001^{*}$ \\
\hline \multirow{4}{*}{$\begin{array}{l}\frac{0}{00} \\
\stackrel{=}{=}\end{array}$} & & Male & 1 & 1 & 3 & 3 & 2 & 10 & & & \\
\hline & $\frac{\bar{d}}{0}$ & $\%$ & (5.9) & $(5.9)$ & $(17.6)$ & $(17.6)$ & $(11.8)$ & & & 1 & \\
\hline & ฐ & FM & 0 & 3 & 2 & 0 & 2 & 7 & 4.821 & 4 & 0.306 \\
\hline & & $\%$ & $(0.0)$ & $(17.6)$ & $(11.8)$ & $(0.0)$ & $(11.8)$ & & & & \\
\hline \multirow{5}{*}{$\begin{array}{l}\bar{\pi} \\
0 \\
0\end{array}$} & & Male & 1 & 1 & 29 & 33 & 54 & 118 & & & \\
\hline & $\frac{\bar{d}}{0}$ & $\%$ & $(0.7)$ & $(0.7)$ & (19.3) & $(22)$ & (36) & & & 4 & $0.000^{*}$ \\
\hline & ฐ & FM & 0 & 6 & 6 & 12 & 8 & 32 & 21.577 & 4 & $0.001 *$ \\
\hline & & $\%$ & $(0.0)$ & (4) & (4) & (8) & (5.3) & & & & \\
\hline & $\begin{array}{l}\text { Tot } \\
\%\end{array}$ & & $\begin{array}{c}1 \\
(0.7)\end{array}$ & $\begin{array}{c}7 \\
(4.7)\end{array}$ & $\begin{array}{c}35 \\
(23.3)\end{array}$ & $\begin{array}{c}45 \\
(30)\end{array}$ & $\begin{array}{c}62 \\
(41.3)\end{array}$ & $\begin{array}{c}150 \\
(100)\end{array}$ & & & \\
\hline
\end{tabular}

** represents significance at 0.05 error margin; figures in brackets represent percentages.

FM abbreviation used signifies females.

Source: own elaboration based on the survey $(n=150)$.

As shown in Table 1, the majority (39.1\%) of aquapreneurs were married men aged 44 years and above, while only $12 \%$ of the married women were aged 39 to 43 years old. A meagre $5.9 \%$ were single men aged 23 years and below. The results highlight that people who venture and actively involve themselves in aquapreneurship were married men (39.1\%) 44 years old or more, with a very low proportion of married women (12\%) aged between 39 
to 43 years old. This is not surprising because most of the participants are above 35 years old, which signifies the average marriage age. The low level of aquapreneurial involvement among women can be attributed to their household parental responsibilities. Ngota, Mang'unyi, and Rajkaran (2018) state that it is rooted in most African culture for men to be more involved in activities that financially support their families, while women take charge of household activities. This accounts for the gender imbalance in aquapreneurship involvement, indicating that men are more exposed to high-risk ventures than women.

Moreover, aquapreneurship is very low (5.6\%) among the young population of 23 years old and below. This may be explained by the level of expertise and capital needed to get involved in this sector. Furthermore, it appeared that there is a significant statistical relationship between gender, marital status, and age $\left(\chi^{2}[3, N=150]=18.980, \rho=0.001\right)$. The implication is that, aquaculture venture in Cameroon is inclusive, involving individuals of all the different age strata. This finding corroborates Okoronkwo and Ume's (2013) study on small-scale fish cultivators in Cross River State in Nigeria, which affirms that the mean age of table size fish agriculturists in their study was 44.5 years.

Table 2. Socio-economic attributes of respondents

\begin{tabular}{|c|c|c|c|}
\hline Demographic attributes & No of observations & $\%$ & Cumulative \\
\hline Level of education & & & \\
No education & $\mathbf{3}$ & 2 & 2 \\
Primary & $\mathbf{5}$ & 3.3 & 5.3 \\
High school & $\mathbf{4 3}$ & 28.7 & 34 \\
Tech or university & $\mathbf{9 9}$ & 66 & 100 \\
Total & $\mathbf{1 5 0}$ & 100 & \\
\hline Years' of operation & & 23.3 & 23.3 \\
<5 years & $\mathbf{3 5}$ & 49.3 & 72.7 \\
5-10 years & $\mathbf{7 4}$ & 21.3 & 94.0 \\
11-15 years & $\mathbf{3 2}$ & 3.3 & 97.3 \\
16-20 years & $\mathbf{5}$ & 2.7 & 100.0 \\
>20 & $\mathbf{4}$ & 100 & \\
Total & $\mathbf{1 5 0}$ & & 26.6 \\
Food business & & 26.6 & 35.3 \\
Business \& farming & $\mathbf{4 0}$ & 8.7 & 42 \\
Oil business & $\mathbf{1 3}$ & 6.7 & 49.3 \\
Part-time business & $\mathbf{1 0}$ & 7.3 & 50 \\
Cocoa farming & $\mathbf{1 1}$ & 0.7 & 50.7 \\
Real estate & $\mathbf{1}$ & 0.7 & 54.7 \\
Restaurant & $\mathbf{1}$ & 4 & 100 \\
Other retailing business & $\mathbf{6}$ & 45.3 & \\
Total & $\mathbf{6 8}$ & 100 & \\
\hline
\end{tabular}

Source: own elaboration based on the survey $(n=150)$.

Education-wise, the findings in Table 2 show that a huge number (66\%) of aquapreneurs had either acquired a technical or university degree, followed by $28.7 \%$ of individuals with a high school certificate, while very few (2\%) aquapreneurs has no educational qualification. This simply implies that aquapreneurship required some level of educational 
background to successfully venture into it. Moreover, a high proportion (36.7\%) of aquapreneurs claimed to have been in business from five to 10 years, with $20 \%$ affirming to have operated their fish farms for over 11-15 years. This suggests that most of the aquapreneurs were new in this venture and have been operating for less than a decade. The question whether individuals who pursued aquapreneurship were involved in other income-generating businesses revealed that the majority (43.3\%) of the aquapreneurs were engaged in other retail businesses to generate additional income. About $26.6 \%$ of respondents said they were engaged in the food business as an additional source of income. However, a meagre proportion ( $0.7 \%)$ of the aquapreneurs were involved in other forms of businesses, such as real estate or cash crops farming like cocoa. I infer from these findings that venturing into aquapreneurship could perhaps be investments in search of additional income. Other businesses and cash crops farming may be the way to raise capital to initiate, maintain, and expand fish farms. These findings imply that even though people are engaged in fish farming, they supplement their income from other sources.

\section{Sources of Fingerlings}

Figure 1 displays three key inputs: the primary source of fingerlings, sources to purchase fingerlings and parents, and where fish are reared (cultivated) in commercial aquaculture production.

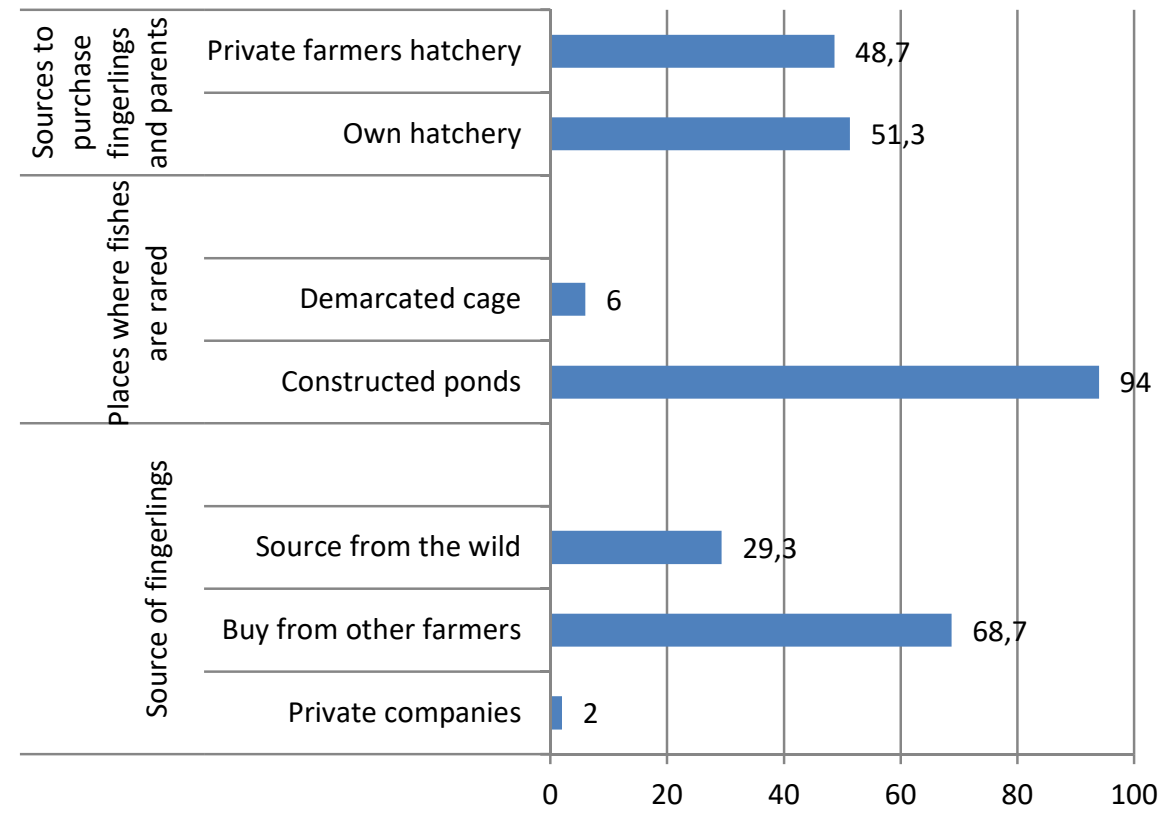

Figure 1. Source of fingerlings, sources to purchase fingerlings, parents, and places where fish are bred

Source: own elaboration based on the survey $(n=150)$.

As shows Figure 1, nearly half of aquapreneurs (51\%) indicated that they have their own hatchery where they source fingerlings, while the other half $(49 \%)$ specified that they 
purchase the fingerlings they need from private farmers. Furthermore, a vast number $(68 \%)$ of aquapreneurs stated that they prefer to purchase parents and fingerlings from other farmers when necessary, meanwhile some (29.3\%) prefer to go to the wild to harvest parents and fingerlings to stock up their ponds, while only a few (2\%) buy from private hatcheries. The different sources could be attributed to the lack of adequate financial resources. I find that there is a significant statistical correlation between sources of fingerlings (at $X^{2}=49.038 ; d f=2 ; P 0.05$ ) and where farmers purchase fingerlings and parents they need. These results may be comparable to studies by some researchers (Agboola, 2011; Ibemere, \& Ezeano, 2014) who state that the majority (65\%) of aquapreneurs prefers to source fingerlings from private hatcheries in contrast to $38 \%$ that source them from governments, and $10 \%$ who source them from the wild. Sourcing fingerlings from guaranteed incubation centres of fish that can be reared is the best practice that guarantees the utilisation of value fish seed with great attributes for development. On the contrary, fingerlings harvested from the wild require more incubation facilities to take care of the demand for fingerlings production in Cameroon.

\section{Water Source, the Means of Filling Ponds, and Predators Affecting Fish Survival}

I was also interested in determining water sources, the means of filling the ponds, and the type of predators that affect fish survival thereby dwindling production capacities.

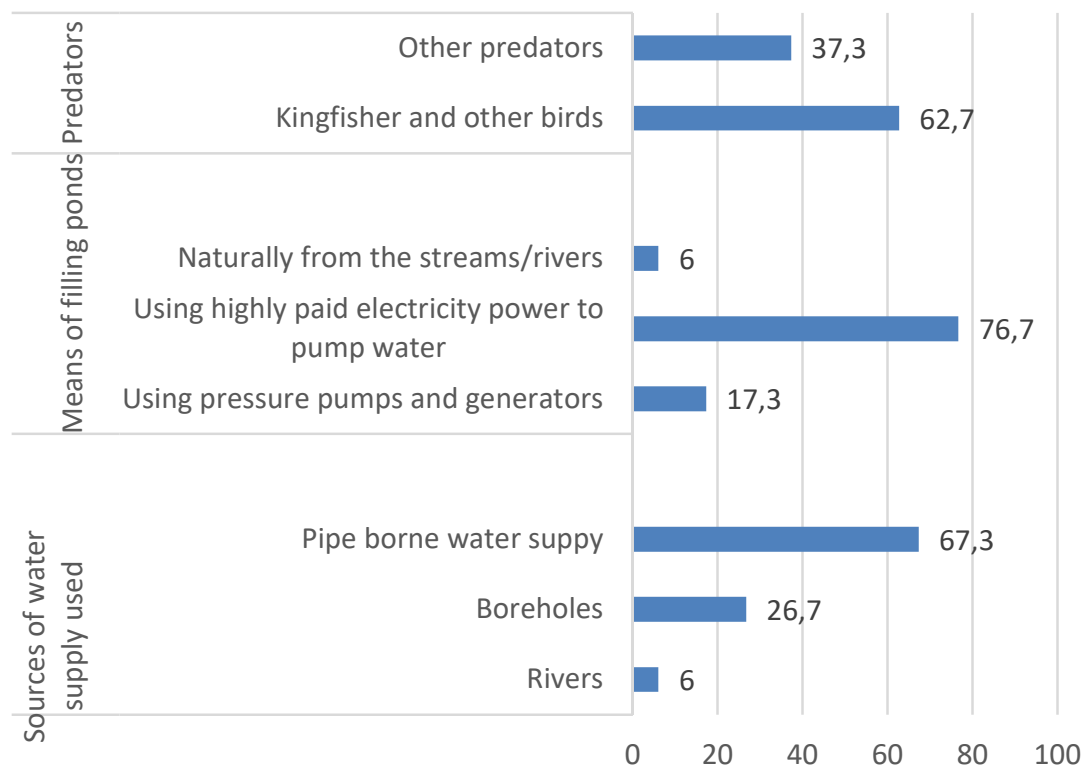

Figure 2. Sources of water, the means of filling ponds, and predators preying on fish Source: own elaboration based on the survey $(n=150)$.

As shown in Figure 2, the majority (67.3\%) of aquapreneurs indicated that they use pipe-borne water supply to fill their ponds, while only a few (6\%) of them use water from a natural running source such as rivers to fill-up their ponds. Meanwhile, using pipe-borne 
water supply to fill-up ponds, $76.7 \%$ of the aquapreneurs complained of paying high electricity bills for pumping water into the ponds. I find that there is a significant statistical correlation between the source of water supply $\left[x^{2}(2, N=150)=150.00, \rho=0.001\right]$ and the means of filling ponds. Moreover, many farmers (63\%) indicated that kingfishers and other birds were considered major predators of their fish, while some $(37 \%)$ indicated that these were other kinds of predators. I find that there is a highly significant statistical correlation between the cost of draining and filling the ponds $\left[x^{2}(1, N=150)=\right.$ 10.878, $\rho=0.001$ ] and the impact of predators on fish farms. Hence, these have a high cost of production which, in turn, impact aquaculture production in Cameroon.

\section{Cost of Construction and Managing Ponds}

Figure 3 reveals that the majority counting 141 (94\%) aquapreneurs faced very high costs both in constructing and managing their ponds, while only nine of them (6\%) state it incurs a moderate cost in both constructing and managing their ponds.

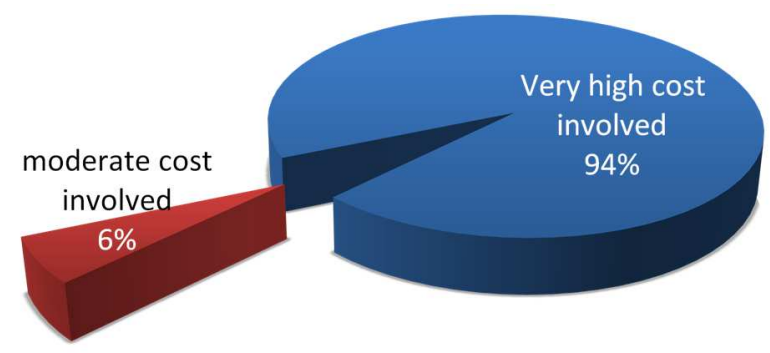

Figure 3. The cost of construction and managing ponds Source: own elaboration based on the survey $(n=150)$.

I went a step further to analyse the data using a correlation matrix as shown in Table 3 below.

Table 3. A correlation matrix amid two variables

\begin{tabular}{|l|l|c|c|}
\hline \multicolumn{2}{|c|}{ Variables } & $\begin{array}{c}\text { What managing } \\
\text { ponds entails }\end{array}$ & $\begin{array}{c}\text { The means of water } \\
\text { supply }\end{array}$ \\
\hline \multirow{2}{*}{$\begin{array}{l}\text { What managing ponds } \\
\text { entails }\end{array}$} & Pearson Correlation & 1 & $0.810^{* *}$ \\
\cline { 2 - 4 } & Sig. (2-tailed) & & 0.000 \\
\cline { 2 - 4 } & $\mathrm{N}$ & 150 & 150 \\
\hline \multirow{2}{*}{$\begin{array}{l}\text { The means of water } \\
\text { supply }\end{array}$} & Pearson Correlation & $0.810^{* *}$ & 1 \\
\cline { 2 - 4 } & Sig. (2-tailed) & 0.000 & 150 \\
\cline { 2 - 4 } & $\mathrm{N}$ & 150 & \\
\hline
\end{tabular}

$*^{* *}$ - correlation is significant at the 0.01 level. ${ }^{*} p<0.05 ; * * p<0.01$.

Source: own elaboration based on the survey $(n=150)$.

This test was to determine whether there was any significant relationship between costs and pond management. This can be attributed to the fact that aquapreneurs who are already established make some profits now, which they invest back into their businesses. A correlation matrix yielded a positive coefficient value of 0.810 and a $p$-value of 0.0001 between the means of filling constructed ponds and the cost of constructing and 
managing the ponds, which was significant at $99 \%$ level of confidence. The results showed that the high costs of constructing, managing and filling the ponds posed a huge challenge for aquapreneurs in conducting successful business operations in Cameroon.

\section{Aquapreneurial Initiation, Growth, and Developmental Challenges}

Furthermore, I asked the respondents to indicate other difficulties they encountered while conducting their aquaculture businesses.

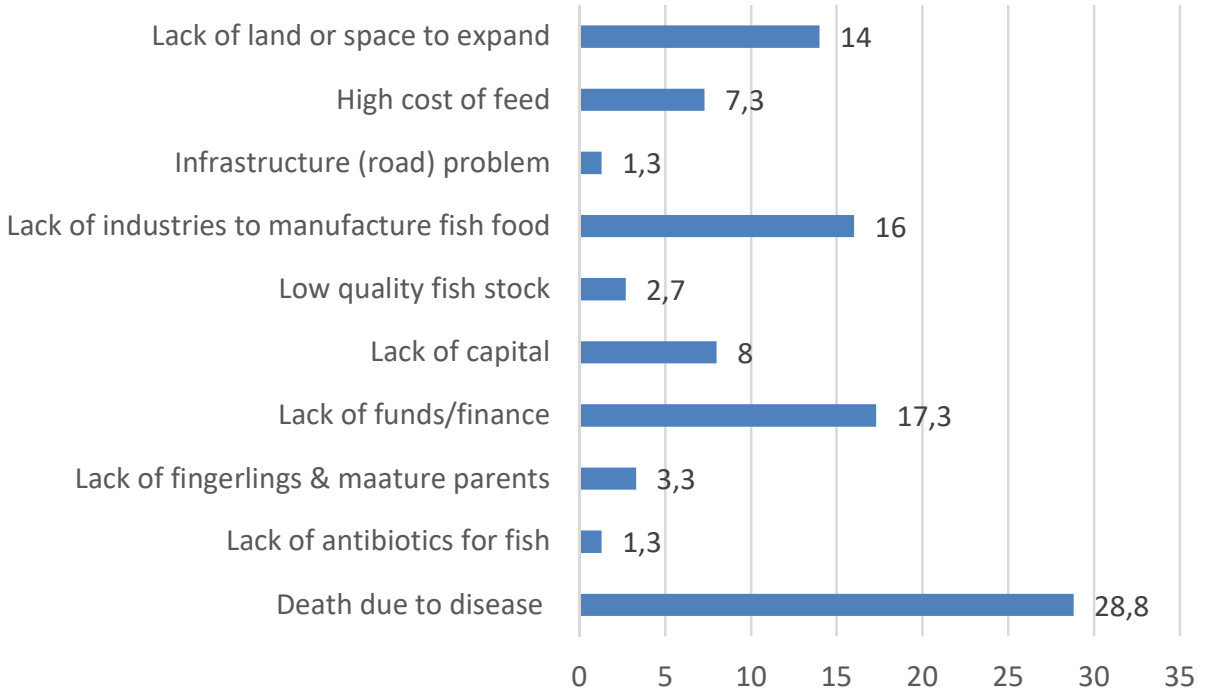

Figure 4. General challenges aquapreneurs encounter Source: own elaboration based on the survey $(n=150)$.

Figure 4 illustrates that many aquapreneurs (28.8\%) generally faced other challenges such as the lack of funds (17.3\%), the absence of industries to produce fish diet (16\%), followed by the absence of space for business expansion (14\%), and the absence of anti-infection agents and infrastructural problem (1.3\%). A study by Shitote, Wakhungu, and China (2012) uncovers that the high cost/the lack of feed was because many of the farmers depended mainly on quite expensive commercial feed. Likewise, a study by the OECD (2010) among fish farming countries notes that fish farming success is due to strong markets, along with access to seed, feed, credit, transportation, and a focus on profits. Aquapreneurs in Cameroon experienced various issues, as elucidated by the respondents of the current research. Authors such as Shitote et al. (2012) establish that the high cost of feed, flooding, the high cost of ponds maintenance, poor security, the lack of financing, the drying of ponds during droughts, and the lack of fingerlings were the most challenges that fish farmers encountered. 


\section{CONCLUSIONS}

The present investigation observed the challenges impeding large scale fish production and the development of aquapreneurship in Cameroon. The examination of the study found that aquapreneurs in Cameroon face significant challenges that hinder the growth and development of aquaculture. This affects investments in this sector as prospects for maximizing profit become pessimistic. The participants were generally negative and doubtful, as they underlined certain crucial issues that hinder the growth and development of aquaculture, including the death of fish due to diseases, the lack of financing, high costs involved in the construction and management of ponds, the effect of predators, the lack of industries to manufacture fish food, the lack of land for expansion, the high cost of feed, and the low-quality bloodstocks that keep on negatively influencing their aquaculture stability and existence. Thus, all this is detrimental to job opportunities and the financial prosperity of the community and Cameroon in general.

Consequently, the following recommendations should assist fish agriculturalists so as to gain the capacity to enhance the usual way of doing things and increase the production, growth, and development of this sector of economy in Cameroon. The government should conduct adequate research to increase the awareness of communities on the impact of aquapreneurship; the government should engage in the growth and production of fingerlings and parents to provide to the aquapreneurs at lower prices. Fish farmers could be trained on feed preparation and fish breeding so as to maintain the constant supply and quality of feed and save on costs for both feed and fingerlings. Formulating guidelines to incorporate aquapreneurs into the financial support systems and further empower them to enter formal credit frameworks will go far in upgrading aquapreneurial growth in Cameroon. Therefore, the Cameroon banking system must improve its policy to accommodate the flexibility of credit for farmers.

\section{REFERENCES}

Agboola, W. (2011). Improving Fish farming Productivity towards achieving food security in Osun State, Nigeria: A socioeconomic analysis. Annals of Biological Research, 2(3), 62-74.

Aldrich, H.E., \& Zimmer, C. (1986). Entrepreneurship through social networks. In D.L. Sexton \& R.W. Smiler (Eds.), The Art and Science of Entrepreneurship (pp. 3-23). Newyork: Ballinger.

Aldrich, H. (1999). Organisations Evolving. New York: Sage Publications.

Atiase, V.Y., Mahmood, S., Wang, Y., \& Botchie, D. (2018). Developing entrepreneurship in Africa: Investigating critical resource challenges. Journal of Small Business and Enterprise Development, 25(4), 644-666.

Badr, M.L., Salwa, O., \& Ahmed, Y. (2015). Perceived barriers to consumption of freshwater fish in Morocco. British Food Journal, 117(1), 274-285.

Barnett, W., Greve, H., \& Park, D. (1994). An evolutionary model of organizational performance. Strategic Management Journal, 15, 11-28.

Béné, C., \& Heck, S. (2005). Fish and food security in Africa. NAGA, WorldFish Center Quarterly, 28(3\&4), 8-13.

Bigwa, C. (2013). Feasibility of aquaculture in Cameroon: the case of the Noun Division in the West region [final project]. 
Blanchflower, D., Oswald, A., \& Stutzer, A. (2001). Latent entrepreneurship across nations? European Economic Review, 45, 680-691.

Bogne Sadeu, C., Mikalasek, O., Barlet, B., Chia, E., Pouomogne, V., \& Eyango, M.T. (2008). Change in the practices and representations of small-scale fish farming activity: a partnership research process in West Cameroon. In 8th International Symposium on Tilapia in Aquaculture 2008. Yaounde, Cameroon: Arizona.edu.

Brandi, C. (2017). Sustainability standards and sustainable development -synergies and trade-offs of transnational governance. Sustain Development, 25, 25-34. https://doi.org/10.1002/sd.1639

Brummett, R.E., Gockowsky, J., Pouomogne, V., \& Muir, J. (2011). Targeting Agricultural Research and Extension for Food Security and Poverty Alleviation: A case study of Fish farming in Central Cameroon. Aquaculture Economics \& Management, 8(5/6), 1-10.

Chigunta, F. (2017). Entrepreneurship as a possible solution to youth unemployment in Africa. Laboring and Learning, 10, 433-451.

Clausen, T. (2006). Who identifies and exploits entrepreneurial opportunities. Retrieved from www.ccsr.ac.iuk on June 17,2017.

Conijn, J.G., Bindraban, P.S., Schröder, J.J., \& Jongschaap, R.E. (2018). Can our global food system meet food demand within planetary boundaries.? Agriculture Ecosystem Environmnet, 251, 244-256. https://doi.org/10.1016/J.AGEE.2017.06.001

Davidson, P., \& Honing, B. (2003). The role of social and human capital among nascent entrepreneurs. Journal of Business Venturing, 20, 121.

Dvouletý, O., Gordievskaya, A., \& Procházka, D. (2018). Investigating the relationship between entrepreneurship and regional development: Case of developing countries. Journal of Global Entrepreneurship Research, 8(1), 16.

Dvouletý, O., \& Orel, M. (2019). Entrepreneurial Activity and Its Determinants: Findings from African Developing Countries. In V. Ratten, P. Jones, V. Braga, \& C.S. Marques (Eds.), Sustainable Entrepreneurship: The Role of Collaboration in the Global Economy (pp. 9-24). Cham: Springer.

Edwards, P. (1997). Sustainable food production through aquaculture. Aquaculture Asia, 2(1), 4-7.

Evans, M.D. (1989). Immigrant Entrepreneurship: Effects of Ethnic Market Size and Isolated Labor Pool. American Sociological Review, 54(6), 950-962.

FAO. (2004). Fishery Statistics. Yearbook of Aquaculture Production, 94(2), 193.

FAO. (2013). Global aquaculture production statistics for the year 2011.

FAO. (2015). State of the World fisheries and aquaculture 2015. Rome.

FAO. (2017). The state of food and agriculture leveraging food systems for inclusive rural transformation. Rome: FAO.

Frese, M., \& de Kruif, M. (2000). Psychological success factors of entrepreneurship in Africa: A selective literature review. In Success and failure of microbusiness owners in Africa. Westport, CT: Quorum Books.

Frimpong, S.K., \& Adwani, A. (2015). The challenges and prospects of fish farming in Ghana: A Project Management perspective. International Journal of ICT and Management, 3(2), 29-34.

George, G., Kotha, R., Parikh, Alnuaimi, T., \& Bahaj, A. (2016). Social structure, reasonable gain, and entrepreneurship in Africa. Strategic Management Journal, 37(6), 1118-1131.

Goddek, S., Delaide, B., Mankasingh, U., Ragnarsdottir, K., Jijakli, H., \& Thorarinsdottir, R. (2015). Challenges of sustainable and commercial aquaponics. Sustainability, 7, 4199-4224. https://doi.org/10.3390/su7044199

Goddek, S., Joyce, A., Kotzen, B., \& Burnell, M. (2019). Aquaponics Food Production Systems 
Combined Aquaculture and Hydroponic: Production Technologies for the Future Funded. In S. Milliken \& H. Stander (Eds.), Aquaponics and Social Enterprise. Cham: Springer.

Goddek, S., \& Keesman, K. (2018). The necessity of desalination technology for designing and sizing multiloop aquaponics systems. Desalination, 428, 76-85. https://doi.org/10.1016/j.desal.2017.11.024

Godfray, H.C.J., Beddington, J.R., Crute, I.R., Haddad, L., Lawrence, D., Muir, J.F., Pretty, J., Robinson, S., Thomas, S.M., \& Toulmin, C. (2010). Food security: the challenge of feeding 9 billion people. Science, 327, 812-818. https://doi.org/10.1126/science.1185383

Håstein, T.B., Hjeltnes, A., Lillehaug, J., Skåre, U., Berntssen, M., \& Lundebye, A. (2006). Food safety hazards that occur during the production stage: challenges for fish farming and the fishing industry. Review Science Technology, 25(2), 607-625.

Holtz-Eakin, D., Joulfaian, D., \& Rosen, H. (1994). Sticking it out: Entrepreneurial Survival and Liquidity Constraints. Journal of Political Economy, 1, 102.

Hurst, E., \& Lusardi, A. (2004). Liquidity Constraints, Household Wealth, Entrepreneurship. Journal of Political Economy, 2, 112.

Ibemere, I.F., \& Ezeano, N. (2014). Status of fish farming in Rivers state, Nigeria. Journal of Fisheries and Aquatic Sciences, 9(5), 321-329.

Ifejika, P.I., Oladosu, I.O., Asadu, A.N., Ayanwuyi, E., Sule, A.M., \& Tanko, M. (2015). Assessment of aquapreneur willingness to pay for mobile phone advisory services in anambra state, Nigeria. International Journal of Agriculture and Forestry, 5(6), 330-338.

Ifejika, P. (2015). Assessment of fish farmers' information behaviour towards mobile phone innovative platform services in selected states of Nigeria. Ladoke Akintola University of Technology, Ogbomoso, Oyo State.

IUCN. (2007). The advantages and disadvantages of culturing fish. Retrieved from https://doi.org/10.3390/w9030182 on July 12, 2017.

Junge, R., König, B., Villarroel, M., Komives, T., \& Jijakli, M. (2017). Strategic points in aquaponics. Water, 9, 182. https://doi.org/10.3390/w9030182

Khan, M.A., Khan, S., \& Miyan, K. (2011). Aquaculture as a food production system: A review. Biology and Medicine, 3(2), 291-302.

Kiggundu, M. (2002). Entrepreneurs and entrepreneurship in Africa: What is known and what needs to be done. Journal of Developmental Entrepreneurship, 7(3), 239.

Kim, P, Aldrich, H.E., \& Keister, L. (2003). Access (not) denied: The Impact of financial, human and cultural capital on becoming a Nascent Entrepreneur (635-378 No. 1). New York.

Kloas, W, Groß, R, Baganz, D, Graupner, J, Monsees, H, Schmidt, U, Staaks, G, Suhl, J, Tschirner, M, Wittstock, B, Wuertz, S, Zikova, A., \& Rennert, B. (2015). A new concept for aquaponic systems to improve sustainability, increase productivity, and reduce environmental impacts. Aquacuture Environment Interaction, 7, 179-192. https://doi.org/10.3354/aei00146

Kshetri, N. (2011). Institutional and economic foundations of entrepreneurship in Africa: An overview. Journal of Developmental Entrepreneurship, 16(1), 9-35.

Kuada, J. (2015). Entrepreneurship in Africa - A classificatory framework and a research agenda. African Journal of Economic and Management Studies, 6(2), 148-163.

Lashitew, A.A., \& van Tulder, R. (2017). Inclusive business in Africa: Priorities, strategies and challenges. Entrepreneurship in Africa, 15, 71.

Lehane, S. (2013). Fish for the future: aquaculture and food security. Strategic analysis paper, Future Directions International. Retrieved from (tu wstawić podaną stronę http) on July 12, 2017.

Mathews, J. (2002). A Resource-Based View of Schumpeterian economic dynamics. Journal of 
Evolutionary Economics, 12(1/2), 29-55.

Miller, J.W., \& Atanda, T. (2010). The rise of peri-urban aquaculture in Nigeria. In The 25th annual conference of Fisheries Society of Nigeria (FISON). ASCON Badagry, Lagos State: FISON.

Milliken, S., \& Stander, H. (2019). Aquaponics and Social Enterprise. In Aquaponics Food Production Systems (pp. 607-619). Switzerland AG: Springer.

Mohtasham, J. (2015). Review Article-Renewable Energies. Energy Procedia, 74(2015), 1289-1297.

Munemo, J. (2012). Entrepreneurship in developing countries: Is Africa different? Journal of Developmental Entrepreneurship, 17(1), 1250004.

Mwangi, H. (2008). Aquaculture in Kenya, Status Challenges and Opportunities. Nairobi, Kenya.

Ndah, H.T., Knierim, A., \& Ndambi, O. (2011). Fish pond aquaculture in Cameroon: A field survey of determinants for farmers' adoption behaviour. The Journal of Agricultural Education and Extension, 17(4), 309-323.

Ngota, B.L., Rajkaran, S., Balkaran, S., \& Mang'unyi, E. (2018). Factors impeding African immigrant entrepreneurs' progression in selected small and medium enterprises: Evidence from a local municipality in South Africa. South African Journal of Business Management, 49(1), 1-9. https://doi.org/10.4102/sajbm.v49i1.10

OECD. (2010). Barriers to fish farming Development as a Pathway to Poverty Alleviation and Food Security. Retrieved from http://www.oecd.org/eco/surveys/South Africa 2013 Overview FINAL.pdf on July 18, 2016.

Okoronkwo, M.O., \& Ume, S. (2013). Evaluation of the socioeconomic factors influencing adoption of catfish production technologies in Anambra State, Nigeria. International Journal of Agriculture and Rural Development, 16(1), 1425-1430.

Osure, G. (2011). Introduction to Aquaculture. Greener Journal of Agricultural Sciences, 33(1), 3-7.

Oyase, A., \& Jemerigbe, R. (2016). Contribution of aquaculture to poverty reduction and food security in Nigeria. International Journal of Applied Microbiology and Biotechnology Research, 4, 26-31.

Penrose, E. (1959). The Theory of the Growth of the Firm (3rd ed.). New York: Oxford University Press.

Pouomogne, V., Brummett, E.R., \& Gatchouko, M. (2010). Impacts of aquaculture development projects in Western Cameroon. Journal of Applied Aquaculture, 22(3), 93-108. https://doi.org/1

Pouomogne, V., \& Pemsl, D. (2008). Country Case Study: Development and Status of Freshwater Aquaculture in Cameroon. Yaounde.

Ratten, V., \& Jones, P. (2018). Bringing Africa into entrepreneurship research. In African Entrepreneurship. Cham: Palgrave Macmillan.

Rey, S. (2018, December 3). How Africa wins through design-centered and learned entrepreneurship. Business Report, pp. 1-2. Retrieved from www.iol.co.za/business-report/opinion/how-africa-winsthrough-design-centered-and-learned-entrepreneurship-18364475\%0D on March 18, 2019.

Röschenthaler, U., \& Schulz, D. (2015). Cultural entrepreneurship in Africa. London: Routledge.

Sanusi, S.M., \& Danasabe, K. (2015). Problems' and prospects of small -scale fish farming in Minna Agricultural Zone of Niger State, Nigeria, and its implications on increased fish food security. International Journal of Agricultural Research and Review, 3(2), 157-160.

Shane, S.A., \& Eckhardt, J. (2003). The individual-opportunity nexus. Handbook of entrepreneurship research: An interdisciplinary survey and introduction. In Z.J. Acs and D.B. Audretsch (Ed.). Boston, MA: Kluwer Academic Publishers.

Shitote, Z., Wakhungu, J., \& China, S. (2012). Challenges facing fish farming development in Western Kenya. Greener Journal of Agricultural Sciences, 3(5), 305-311.

Somerville, C., Cohen, M., Pantanella, E., Stankus, A., \& Lovatelli, A. (2014). Small-scale aquaponic 
food production. Integrated fish and plant farming (No. 589). Rome.

Sriram, V., \& Mersha, T. (2010). Stimulating entrepreneurship in Africa. World Journal of Entrepreneurship, Management and Sustainable Development, 6(4), 257-272.

\section{Author}

\section{Bernard Lama Ngota}

Lecturer at the Department of Business Management, Walter Sisulu University, South Africa. He has a Bachelor of Commerce in Management (University of South Africa); Bachelor of Commerce in Business Management (Honours; Walter Sisulu University); Master of Commerce in Business Management (Walter Sisulu University); PhD candidate in Commerce (Business Management; Nelson Mandela University). His research interests include entrepreneurship and small business management, along with marketing and innovative development in marketing and technology. He already authored or co-authored several articles in renowned journals (for instance SAJBM, IJAEE, IRMM).

Correspondence to: Mr. Bernard L. Ngota, Walter Sisulu University, Private Bag X1, Mthatha 5117, South Africa, e-mail: bngota@wsu.ac.za; bencolam@gmail.com

ORCID (i) http://orcid.org/0000-0002-0767-4118

\section{Acknowledgements and Financial Disclosure}

This study is a research development project in which the researcher is part of in Cameroon, as such the study is self-funded. No research subsidy was received from anywhere. Thanks to the researcher's hard-work, and special appreciation to EBER for accepting to publish the article.

\section{Copyright and License}

(9)(1) $\Theta$

This article is published under the terms of the Creative Commons

Attribution - NoDerivs (CC BY-ND 4.0) License

http://creativecommons.org/licenses/by-nd/4.0/

Published by Cracow University of Economics - Krakow, Poland 